\title{
Neoliberalism in Higher Education as a Challenge for Future Civilization
}

\section{Roman Oleksenko}

\author{
Doctor of Philosophical Sciences, Associate Professor, Bogdan Khmelnitsky Melitopol \\ State Pedagogical University (Melitopol, Ukraine) \\ E-mail: roman.xdsl@ukr.net \\ ORCID: 0000-0002-2171-514X
}

\section{Valentin Molodychenko}
Doctor of Philosophical Sciences, Associate Professor, Bogdan Khmelnitsky Melitopol State Pedagogical University (Melitopol, Ukraine)
E-mail: molodychenko@gmail.com
ORCID: 0000-0002-2508-1383

\section{Nina Shcherbakova}

$\mathrm{PhD}$, Senior Lecturer, Tavria State Agrotechnological University (Melitopol, Ukraine)

E-mail: rnk-07@ukr.net

ORCID: 0000-0003-2632-2641

The logic of neoliberal reforms in higher education stills a subject of wide scientific discussion where dialectics of today profit and long-term strategies is problematized. Author tried to demonstrate the historical preconditions of neoliberal reforms in higher education (liberalism theory, Washington consensus, GATS) and underline the potential of futurological studies for next generations where education will probably lost one's humanistic essence. The social and cultural landscape of contemporary civilization meets with the lack of effective mechanisms for providing the progress of civilization in humanistic way. Author tried to perform a review of contemporary 'order of the day' of higher education modernization at the context of neoliberal reforms hoping to initiate deeper discussion of possible scenarios of this tendency realization.

Keywords: neoliberalism, liberalism, higher education, futurology of higher education, entrepreneurial university.

Received 11 May 2017; accepted 21 August 2017

Philosophy and Cosmology, Volume 20, 2018: 113-119

DOI: $10.29202 /$ phil-cosm/20/10

\footnotetext{
(C) Oleksenko, Roman, 2018

(C) Molodychenko, Valentin, 2018

(C) Shcherbakova, Nina, 2018
} 


\section{Introduction}

Modern society is an arena for implementation of neoliberal ideology last 30 years. Most of the spheres of social life transforms own fundamental principles of activity to fit neoliberal metaphor. There is a full-scale debatable at philosophic, political, educational and other scientific spheres depending the advantages and disadvantages of neoliberal reforms, but the heart of the matter still the same - neoliberalism becomes one of the important metaphors of modernization changes at the beginning of the $21^{\text {th }}$ century. Our world becomes more and more pragmatic. Competitive activity becomes the general instrument for achievement of successful position at any spheres of activity.

From one hand, pragmatic nature of neoliberal reforms is an adequate response for globalization challenges. From the other hand, pragmatic approaches usually are oriented on present-day profit (in different connotations), but futurological aspect receives marginal status due to this fact. Becoming a part of global neoliberal changes, higher education sphere represents the interesting case where neoliberal approaches demonstrate ones' contradictive nature taking to account the need to save educational role for sustainable development of human culture. We are the bystanders of situation when most of phenomena meant to be the resource of civilizational development changes ones' role at pragmatic neoliberal society raising the question about the challenges for human civilization. Exploring educational orientations to the future, Sarah Amsler and Facer Keri underline: "Because education is so often dedicated to the formation of future persons, the realization of social futures, and the advancing of historical projects, this situation raises fundamental questions for educators... The debates of the $20^{\text {th }}$ century were characterised not by the question of whether it is possible to create human beings and social futures through education, but which subjects and societies were desirable and how methodologically to educate them" [Amsler \& Keri, 2017: 7].

We see that today universities are pushed to solve many new tasks while ones' main (educational and cultural) roles get more and more marginalized. Universities become the bearers of neoliberal approaches instead of social welfare idea. We all understand that social evolution is an inevitable fact and it has no sense to spread alarmist approaches like luddites did. At the same time, we understand that today profit can become too danger criterion for longtime strategies of social development. Market ideology should fit spiritual role of universities to grant the humanistic future for people's generations.

In addition, it is important to take into account that there is no universal strategy for all the people - each "good" strategy implementation feels the pressure of specific social and cultural landscape demonstrating the wide range of results (from success to deep crisis). It is very important for understanding of the processes of higher education modernization at postSoviet social and cultural landscape [Aleksandrova, 2016; Naumenko, 2017; Svyrydenko, 2017]. The contradictions of realization of neoliberal ideology at these specific conditions are described by Anna Smolentseva in a following way: "The breakdown of the socialist bloc and the rise of neoliberal ideologies had a crucial ongoing impact, direct or indirect, on the development of societies around the world. The deconstruction of the communist state in the former USSR seemed to give a hope for a better life, better society and better education - free of communist ideologies, less state-controlled, less bureaucratized, more individual-centered and diverse in terms of content and opportunities. However, after several years the spirit of hope dissipated; and now after 25 years of new independence it has become clear that in many ways those aspirations were not realized as expected: higher education is largely state controlled, bureaucratized, not very diverse, and carries an ideological function for the state" [Smolentseva, 2017: 1092]. Therefore, the question about neoliberal future of 
higher education in general as well one's national implications stills the subject of scientific discussion. It is important to understand for whom and for what higher education should work and does work; what higher education should give to students, economy and society and what it does give in reality [Smolentseva, 2017: 1092].

\section{(Neo) liberalism as a Multidisciplinary Concept}

Discussing the neoliberalism in higher education as a challenge for future generation, it has sense to expose the main approaches of neoliberal (liberal) theory. Liberalism is contradictive social concept trying to conceptualize the idea of human liberty as an axiological imperative of human society development: society should grant and promote the individual possibilities for actualization of free choice. From the other side, too wide understanding of liberalism provokes a lot of criticism for this theory, but the theory still concentrated around the idea of human freedom. In general, liberal theory fits the logic democratic transformations, overcoming of discriminations and social pressure, external control and intervention.

Liberal society is comprehended as individuals association where separate person has own vision of respectable good life. The role of liberal society is to promote the individual life projects for positive liberty actualization where basic values are integrity, individual rights, and diversity. The key guidelines of liberalism were formulated as the beginning of $17^{\text {th }}$ century, but the precious conceptualization was performed at the end of $19^{\text {th }}$ century and at the beginning of the $20^{\text {th }}$ century (John Stuart Mill, Aron Raymon, Karl Raimund Popper and others).

Last quarter of the $20^{\text {th }}$ century was the epoch of liberal ideas re-conceptualization. The neoliberalism concept became a result of new liberal concept formulation. This new concept became a platform for substantiation of social order at developed countries such as USA, Great Britain and so on. The main conceptual idea of neoliberalism is understanding of market mechanisms (competition, profit, success and so on) as the principal mechanisms of individual freedom achievement. Even more, neoliberalism tries to implement this principle as the rule for social and political order. At the end last century, neoliberalism became social and political theory (and practice) for social life organization, where competitive fight started being understood as normative procedure. Victor Manuel Isidro Luna defined six ways to increase the rate of profit neoliberals have successfully used:

1. To defeat unions and inhibit their organization;

2. To privatize profitable State Owned Enterprises (SOEs) that require low capital (so the investment is low and the profit high);

3. To protect the now private enterprises of competition;

4. To ensure internal security through the police and army;

5. To maintain low inflation, high interest rates, and free mobility of capital in order to provide a good environment for financial activities;

6. To transfer resources from the poor people to the wealthy people [Luna, 2015: 39].

It looks heuristic to appeal to ideas of Carolyn Hardin conceptualized at her research "Finding the "neo' in neoliberalism" [Hardin, 2014]. Author underlines that neoliberal concept reconsiders the principles of liberalism transforming social order according to corporative, competitive logic: 'I want to suggest that the 'neo' in neoliberalism is given in part by the role of the corporation. It seems that the epistemological project of neoliberalism refigures society as an economic system of corporations. Individuals are refigured as corporations or entrepreneurs and corporations are treated as individuals. Rights are refigured as corporate rights, freedoms as corporate freedoms and even apparatuses of security are aimed at 
corporations ('corporate welfare'). The free, well functioning society is one composed of corporations, whether of one or many individuals, and operating according to corporate logic" [Hardin, 2014: 17].

It is easy to see that neoliberal ideology logically raises the role of market mechanisms of social development; actualizes the role of international organizations (World Bank, World Trading Organization etc); reduces the level of social expenses (using privatization mechanisms at the spheres of education, health protection); free movement of finances and resources. Mentioned approaches were formulated more detailed at the text of Washington consensus (recommendations for Latin America and developing countries) contained mentioned principles for economic modernization [Burki et al., 1998]. At the result, all the spheres of social life including educational sphere initiated wide modernization processes. Market approaches "recompense" for effectiveness and "punish" for ineffectiveness. The question is logic of effectiveness, especially at higher education sphere.

\section{Educational Connotations of Neoliberal Concept}

Let us review the changes performed at the sphere of higher education according to new approaches at social architecture. Shahid Javed Burki, famous researcher of neoliberal modernization at higher education sphere, formulated some key provisions of this transformation:

- Privatization at higher education sphere;

- Reducing of direct state financial support of educational sphere;

- Commercialization of education (competition between the educational institutions; orientation of profit; production and sale of educational services);

- Creation of global market of educational services;

- Integration of national educational systems into the global educational economy [Burki et el., 1998: 13-15].

Traditional universities transformed ones' major principles implementing the idea of "entrepreneurial university." For us it is important to estimate the role of these entrepreneurial factories of knowledge and educational services for future civilization. Neoliberalism initiates transformative processes at the "core" of universities making this institution similar to factories with corresponding managerial system (system of certification for teachers, investment policy and so on) creating special business environment at educational sphere. Logically, long-term strategies and non-profit roles of higher education become marginalized in general. University as a union of academician and students becomes the sphere of actualization of management principles with corresponding entrepreneurial corporative culture. This environment is more sensible for customer needs then to traditional values of universities such as academic freedom, translation of cultural heritage and so on.

To understand the new dimension of higher education everyday being, we want to use the list of neoliberal "markers" of this being. We agree with the list formulated by John Clark at his article "Living with/in and without neo-liberalism" [Clarke, 2008]. Author postulates the following list of neoliberalism manifestations: states, spaces, logics, techniques, technologies, discourses, discursive framework, ideologies, ways of thinking, projects, agendas, programs, governmentality, measures, regimes, development, ethno-development, development imaginaries, global forms of control, social policies, multiculturalism, audit cultures, managerialism, restructuring, reform, privatization, regulatory frameworks, governance, good governance, NGOs, third sector, subjects, subjectivities, individualization, professionalization, normalization, market logics, market forms of calculation, the 
destatalization of government and the degovernmentalization of the state [Clarke, 2008: 138]. We stand on position that mentioned "markers" also help to describe the essence of neoliberal (entrepreneurial) universities.

\section{GATS as a Challenge for Idea of University}

Until the initiation of radical transformation (ideological, institutional ones) at the sphere of higher education, caused by neoliberal reforms, higher education was comprehended in terms of social welfare: students and educators manifested the ethos of ones' responsibility for future of human mankind and the 'social membranes' to the sphere of education were not too dense. Neoliberal logic changed the terminological apparatus of educational sphere where concept of 'educational service' received very significant role.

We said that Washington consensus was an important step for formulating of basic principles of neoliberal social and political practice. For educational sphere, the value has General Agreement on Trade in Services (1995). This fundamental document was formulated and signed by World Trading Organization members accordingly to following motives:

"Recognizing the growing importance of trade in services for the growth and development of the world economy;

Wishing to establish a multilateral framework of principles and rules for trade in services with a view to the expansion of such trade under conditions of transparency and progressive liberalization and as a means of promoting the economic growth of all trading partners and the development of developing countries;

Desiring the early achievement of progressively higher levels of liberalization of trade in services through successive rounds of multilateral negotiations aimed at promoting the interests of all participants on a mutually advantageous basis and at securing an overall balance of rights and obligations, while giving due respect to national policy objectives" [GATS].

According to this point of view, higher education became an education service with corresponding marketing ideology. This fact actualized the series of ethical problems such estimation of risks of spiritual losses on the way of reduction of higher education up to simple service buying. It sounds logical, that marketing neoliberal ideology may cause new social gaps and forms of discrimination. In UNESCO report, Dr. Jane Knight of the University of Toronto, an expert in the internationalisation of higher education, says that many aspects of GATS are open to interpretation, and many nations have yet to fully engage in the process, at least in respect of the potential implications for education: some view GATS as a positive force, accelerating the influx of private and foreign providers of higher education into countries where domestic capacity is inadequate: other take a more negative view, concerned that liberalisation may compromise important elements of quality assurance and permit private and foreign providers to monopolise the best students and most lucrative programmes [Knight, 2002: 2]. This approach corresponds our point of view that future impact of neoliberal changes at higher education sphere is far from clear conceptualization.

\section{Conclusions}

At the article, we tried to perform an explication of challenges of neoliberal reforms at higher education sphere for future generations. Our main methodological point of view was not alarmist by the nature, we understand that changes take place and neoliberal reforms look 
corresponding to wide processes of globalization, transition to information society and so on. The question was in following: does contemporary neoliberal activity take into account the long-term strategies of human civilization development?

For most of educators, it is hard to apply the fact that education now is, in general, the same as haircut, tourism, car rent or other kinds of services. Form our point of view, the social and cultural landscape of contemporary civilization meets with the lack of effective mechanisms for providing the progress of civilization in humanistic way. We see that art becomes rather a tool for aggressiveness actualization loosing one's traditional esthetic component. The family becomes a weak tool for personality socialization. The education becomes an educational service avoiding one's roles of deep transformation of personality world-view orientations. At these conditions, dark side of human nature lost one's traditional supervisors and can actualize in big scales raising the questions about the 'face' of future civilization. Author tried to perform a review of contemporary 'order of the day' of higher education modernization at the context of neoliberal reforms hoping to initiate deeper discussion of possible scenarios of this tendency realization. Author tried to demonstrate the historical preconditions of neoliberal reforms in higher education (liberalism theory, Washington consensus, GATS) and underline the potential of futurological studies for next generations where education will probably lost one's humanistic essence.

\section{References}

Aleksandrova, Nataliya. Cross-Cultural Competence of Specialists Engaged in International Business, Economic Relationships and Management: Content and Structure (With a view to business challenges). Future Human Images. 3(6), 2016: 9-23.

Amsler, Sarah and Facer Keri. Contesting anticipatory regimes in education: exploring alternative educational orientations to the future. Futures. 94, 2017: 6-14. http://dx.doi. org/10.1016/j.futures.2017.01.001

Brenner, Neil, Jamie Peck and Nik Theodore. Variegated neoliberalization: geographies, modalities, pathways. Global Networks - A Journal of Translanional Affairs. 10(2), 2010: 182-222. http://dx.doi.org/10.1111/j.1471-0374.2009.00277.x

Burki, Shahid J., Guillermo Perry and World Bank Group. Beyond the Washington consensus: institutions matter. World Bank, Washington, D.C, 1998.

Clarke, John. Living with/in and without neo-liberalism. Focaal - European Journal of Anthropology. 51, 2008: 135-147. http://dx.doi.org/10.3167/fcl.2008.510110

GATS. General Agreement on Trade in Services (1995). https://www.wto.org/english/docs_e/ legal_e/26-gats.pdf

Hardin, Carolyn. Finding the 'neo' in neoliberalism. In Cultural Studies. 28 (2), 2014: 199221. http://dx.doi.org/10.1080/09502386.2012.748815

Holmes, George and Connor J.Cavanagh. A review of the social impacts of neoliberal conservation: Formations, inequalities, contestations. Geoforum. 75, 2016: 199-209. http://doi.org/10.1016/j.geoforum.2016.07.014

Knight, Jane. Trade in higher education services: The implications of GATS. The Observatory on borderless higher education. London, 2002.

Luna, Victor M.I. From Neoliberalism to Possible Alternatives. Economia Informa. 395, 2015: 35-49. http://doi.org/10.1016/j.ecin.2015.10.004

Lynch, Casey R. "Vote with your feet": Neoliberalism, the democratic nation-state, and utopian enclave libertarianism. Political Geography. 59, 2017: 82-91. http://dx.doi. org/10.1016/j.polgeo.2017.03.005 
Naumenko, Raisa. Management for the Society of the Future: New Trends in the Training for Civil Servants in Ukraine. Philosophy and Cosmology. 19, 2017: 117-125.

Oleksenko, Roman. Homo Economicus in Futures Studies. Philosophy and Cosmology. 19, 2017: 117-125.

Oleksenko, Roman and Lidiia Fedorova. Homo Economicus as the Basis of "Asgardia" Nation State in Space: Perspective of Educational Technologies. Future Human Image. 7, 2017: 126-132.

Smolentseva, Anna. Where Soviet and neoliberal discourses meet: the transformation of the purposes of higher education in Soviet and post-Soviet Russia. Higher Education. 74(6), 2017: 1091-1108, http://dx.doi.org/s10734-017-0111-7

Svyrydenko, Denys. Divided Universities: The Postcolonial Experience of Contemporary Ukrainian Higher Education. Future Human Image. 7, 2017: 128-135.

Venugopal, Rajesh. Neoliberalism as concept. Economy and Society. 44(2), 2015: 165-187. http://dx.doi.org/10.1080/03085147.2015.1013356 